Renewable Agriculture and

Food Systems

\section{cambridge.org/raf}

\section{Themed Content: Ag/Food Systems and Climate Change}

Cite this article: Niles MT et al (2018). Climate change mitigation beyond agriculture: a review of food system opportunities and implications. Renewable Agriculture and Food Systems 33, 297-308. https://doi.org/10.1017/ S1742170518000029

Received: 15 July 2017

Accepted: 29 December 2017

First published online: 13 February 2018

\section{Key words:}

greenhouse gas emissions; diet; food waste; processing; adaptation

Author for correspondence:

Meredith T. Niles, E-mail: mtniles@uvm.edu

\title{
Climate change mitigation beyond agriculture: a review of food system opportunities and implications
}

\author{
Meredith T. Niles ${ }^{1}$, Richie Ahuja², Todd Barker ${ }^{3}$, Jimena Esquivel ${ }^{4}$, \\ Sophie Gutterman ${ }^{3}$, Martin C. Heller ${ }^{5}$, Nelson Mango ${ }^{6}$, Diana Portner ${ }^{3}$, \\ Rex Raimond ${ }^{3}$, Cristina Tirado $^{7}$ and Sonja Vermeulen ${ }^{8}$
}

\begin{abstract}
${ }^{1}$ Department of Nutrition and Food Sciences, Food Systems Program, University of Vermont, 109 Carrigan Drive, 350 Carrigan Wing, Burlington, VT 05405, USA; ${ }^{2}$ Environmental Defense Fund, India; ${ }^{3}$ Meridian Institute, Washington, DC, USA; ${ }^{4}$ Environmental Assessments for Sustainable Agriculture and Food Systems, Wageningen, Netherlands; ${ }^{5}$ Center for Sustainable Systems, School for Environment and Sustainability, University of Michigan, Ann Arbor, MI, USA; ${ }^{6}$ Independent Expert, Nairobi, Kenya; ${ }^{7}$ Institute of Environment and Sustainability, University of California Los-Angeles, California, USA and ${ }^{8} \mathrm{Hoffmann}$ Centre for Sustainable Resource Economy, Chatham House, London, UK
\end{abstract}

\begin{abstract}
A large body of research has explored opportunities to mitigate climate change in agricultural systems; however, less research has explored opportunities across the food system. Here we expand the existing research with a review of potential mitigation opportunities across the entire food system, including in pre-production, production, processing, transport, consumption and loss and waste. We detail and synthesize recent research on the topic, and explore the applicability of different climate mitigation strategies in varying country contexts with different economic and agricultural systems. Further, we highlight some potential adaptation co-benefits of food system mitigation strategies and explore the potential implications of such strategies on food systems as a whole. We suggest that a food systems research approach is greatly needed to capture such potential synergies, and highlight key areas of additional research including a greater focus on low- and middle-income countries in particular. We conclude by discussing the policy and finance opportunities needed to advance mitigation strategies in food systems.
\end{abstract}

(c) Cambridge University Press 2018. This is an Open Access article, distributed under the terms of the Creative Commons Attribution licence (http://creativecommons.org/licenses/ by/4.0/), which permits unrestricted re-use, distribution, and reproduction in any medium, provided the original work is properly cited.

\section{CAMBRIDGE} UNIVERSITY PRESS

\section{Introduction}

It is estimated that agriculture and associated land use change account for $24 \%$ of total global emissions (Smith et al., 2014), while the global food system may contribute up to $35 \%$ of global greenhouse gas (GHG) emissions (Foley et al., 2011; Vermeulen et al., 2012). As a result, food systems - not just agricultural production - should be a critical focus for GHG mitigation (i.e., reduction in, or removal of, current and expected future emissions) and adaptation (i.e., building resilience for emerging and long term climate impacts) strategies. While a significant focus of climate change (CC) research and policy has been on agriculture (e.g., Thornton et al., 2009; Challinor et al., 2014; Varanasi et al., 2016), there is a growing recognition that our food will be affected by CC beyond just production aspects. The anticipated disturbances include sea-level rise that will likely threaten global food distribution (Brown et al., 2015), the occurrence of food safety hazards throughout the food chain (Tirado et al., 2010) and impacts on nutritional quality of certain foods (Myers et al., 2014). Further, CC may result in up to 600 million more people suffering from hunger by 2080 (Yohe et al., 2007), with an additional 24 million undernourished children, almost half of whom would be living in sub-Saharan Africa (Nelson et al., 2009). These changes will impact rates of severe stunting, estimated to increase by $23 \%$ in central sub-Saharan Africa and up to $62 \%$ in South Asia (Lloyd et al., 2011). As a result, we argue here that there is a need to better understand, integrate and create action related to the food system and CC, beyond agricultural production. This focal shift is critical for multiple reasons, including (1) for greater mitigation potential; (2) for exploration of mitigation and adaptation co-benefits, synergies or trade-offs; (3) to identify clear research gaps; and (4) to integrate options that fall both inside and outside of agricultural production (e.g., dietary choices, food waste).

\section{Approach}

A food system 'gathers all the elements (environment, people, inputs, processes, infrastructure, institutions, etc.) and activities that relate to the production, processing, distribution, preparation and consumption of food and the outputs of these activities, including socio-economic 
and environmental outcomes' (HLPE, 2014). Food systems operate within and are influenced by social, economic, political and environmental contexts (Fig. 1). Further, a sustainable food system is one that delivers food and nutrition security for all in such a way that the economic, social and environmental bases to generate food security and nutrition for future generations are not compromised (HLPE, 2014).

Here we synthesize the existing research briefly on preproduction and production, while providing greater detail and context for food system emissions beyond agriculture for the majority of the review. We conclude by discussing some of the pathways or barriers to action-which mechanisms may enable greater shift toward such mitigating behaviors and where future research may be necessary. We consider these opportunities in different country contexts with varying food and economic systems (Table 1). Further, though the focus of this review is primarily on opportunities to mitigate emissions in food systems, we also detail some potential adaptation co-benefits of various mitigation strategies and how they may influence other components of the food system (Table 2). We focus our attention on recent research that builds on the review by Vermeulen et al. (2012).

\section{Opportunities, co-benefits and implications}

CC adaptation and mitigation strategies in the food system require finding more sustainable, resilient and efficient ways of producing, trading, distributing, marketing and consuming diverse and nutritious foods (Tirado et al., 2013). Given the complexity of a food system, and its potential to have non-linear feedbacks and cross-cutting impacts throughout the system, it is

\section{Food System Components, Processes, and Activities}

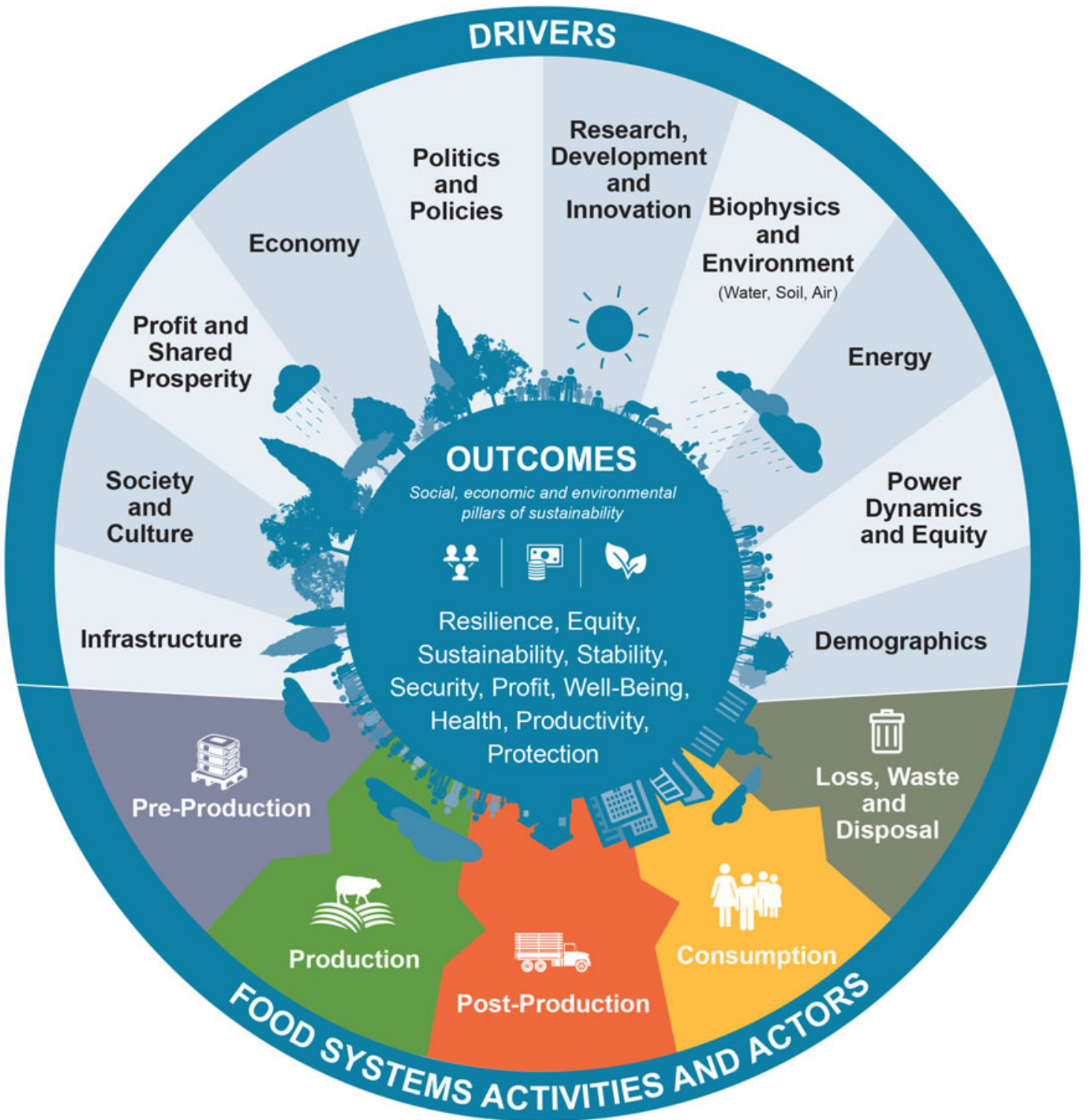

Fig. 1. Identified components, processes and activities within food systems, which are influenced by a diversity of different drivers ranging from infrastructure to demographics. Such drivers within food systems lead to different outcomes fundamental for sustainable development including resilience, equity, sustainability, stability, security, profit, well-being, health, productivity and protection. (Niles et al., 2017). 


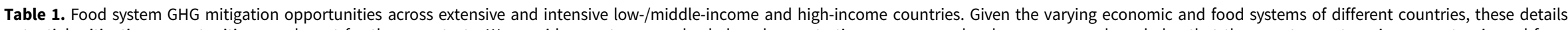

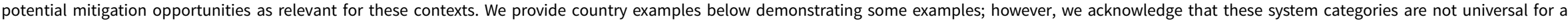
given place. For example, while Brazil, a middle-income country, has intensive agricultural soy and beef systems, it also has vast pasture systems that are not fertilized (Niles et al., 2017)

\begin{tabular}{|c|c|c|c|c|}
\hline \multirow{2}{*}{$\begin{array}{l}\text { Food system } \\
\text { component }\end{array}$} & \multicolumn{2}{|c|}{ Low-/middle-income } & \multicolumn{2}{|c|}{ High-income } \\
\hline & $\begin{array}{l}\text { Extensive (e.g., pastures in Ethiopia, } \\
\text { Colombia) }\end{array}$ & Intensive (e.g., China, Brazil) & $\begin{array}{l}\text { Extensive (e.g., pastures in New Zealand, } \\
\text { Ireland) }\end{array}$ & Intensive (e.g., Japan, United States) \\
\hline Pre-production & $\begin{array}{l}\text { Emissions from these systems are low per } \\
\text { hectare, but high per unit of output. } \\
\text { Using inputs such as fertilizers can } \\
\text { provide benefits for food security and } \\
\text { minimize agricultural expansion when } \\
\text { coupled with land governance and } \\
\text { sustainable efficiencies, providing net } \\
\text { reductions to GHGs. Agroecological } \\
\text { practices with known production } \\
\text { benefits (e.g., manure incorporation, } \\
\text { crop rotation, diversification, push-pull } \\
\text { technologies) can also provide yield } \\
\text { gains and be an alternative to } \\
\text { GHG-intensive inputs and keep } \\
\text { smallholder farmer costs at a minimum }\end{array}$ & $\begin{array}{l}\text { Reduction in manufactured agricultural } \\
\text { inputs where over applied can reduce } \\
\text { GHGs. Switch to renewable and/or } \\
\text { non-coal energy sources for input } \\
\text { production. Incorporation of } \\
\text { agroecological practices could help } \\
\text { reduce the need for manufactured } \\
\text { inputs }\end{array}$ & $\begin{array}{l}\text { Despite extensive pasture systems, } \\
\text { production still relies on } \\
\text { manufactured inputs. Utilizing } \\
\text { high-tech precision agriculture } \\
\text { technologies can help farmers reduce } \\
\text { or better target inputs. Shifting } \\
\text { toward agroecological practices if } \\
\text { possible at large scale may help } \\
\text { minimize inputs and costs }\end{array}$ & $\begin{array}{l}\text { Precision agriculture can minimize } \\
\text { unnecessary inputs and reduce farmer } \\
\text { costs. Inputs, if made domestically, } \\
\text { could utilize best available } \\
\text { technologies to reduce GHGs. Shifting } \\
\text { toward agroecological practices if } \\
\text { possible at large scale may help } \\
\text { minimize inputs and costs }\end{array}$ \\
\hline Production & $\begin{array}{l}\text { Increase nutrient use efficiency, crop } \\
\text { diversification, increase in of perennial } \\
\text { crops, trees cover inside crop and } \\
\text { livestock systems, increased livestock } \\
\text { efficiencies, improved pastures and } \\
\text { forage, increase forage diversity and } \\
\text { availability, increase recycling of } \\
\text { production wastes }\end{array}$ & $\begin{array}{l}\text { Reduced input use where over applied, } \\
\text { increased nutrient efficiency, cover } \\
\text { crops, nitrification and urease } \\
\text { inhibitors, perennial crops, manure } \\
\text { management, enteric feeding strategies, } \\
\text { improved pasture quality, concentrates, } \\
\text { animal health }\end{array}$ & $\begin{array}{l}\text { Reduced input use where over applied, } \\
\text { increased nutrient efficiency, cover } \\
\text { crops, nitrification and urease } \\
\text { inhibitors, perennial crops, enteric } \\
\text { feeding strategies, improved pasture } \\
\text { quality, animal health }\end{array}$ & $\begin{array}{l}\text { Reduced input use where over applied, } \\
\text { increased nutrient efficiency, cover } \\
\text { crops, nitrification and urease } \\
\text { inhibitors, perennial crops, manure } \\
\text { management, enteric feeding } \\
\text { strategies, improved pasture quality, } \\
\text { concentrates, animal health }\end{array}$ \\
\hline $\begin{array}{l}\text { Processing and } \\
\text { transportation }\end{array}$ & $\begin{array}{l}\text { Lack of infrastructure often prevents } \\
\text { processing, manufacturing and } \\
\text { transportation of highly perishable food } \\
\text { and is a significant cause of food waste } \\
\text { in low- income countries. Expansion of } \\
\text { processing and manufacturing with best } \\
\text { available sustainable technologies and } \\
\text { renewable energies can minimize GHGs }\end{array}$ & $\begin{array}{l}\text { High-efficiency systems for processing, } \\
\text { refrigeration and manufacturing will } \\
\text { help minimize GHG emissions. } \\
\text { Renewable energy sources can also } \\
\text { reduce GHG emissions }\end{array}$ & \multicolumn{2}{|c|}{$\begin{array}{l}\text { Given the high reliance on processing, manufacturing, refrigeration and transportation, } \\
\text { systems with low GHG refrigerants can reduce GHGs. Renewable energy sources can } \\
\text { also reduce GHG emissions. Transportation mode shifts can reduce GHGs }\end{array}$} \\
\hline Consumption & \multicolumn{2}{|c|}{$\begin{array}{l}\text { Rising incomes in low- and middle-income countries are driving dietary shifts, which will } \\
\text { influence both public health and GHG emissions. Opportunities to reduce diet-related } \\
\text { emissions should balance the role of livestock in small-scale farmers' livelihoods and } \\
\text { nutritional outcomes for poor consumers }\end{array}$} & \multicolumn{2}{|c|}{$\begin{array}{l}\text { Dietary shifts toward less intensive animal products or more plant-based foods could } \\
\text { reduce GHG emissions, particularly if publicly acceptable. Moderate dietary shifts can } \\
\text { also provide potential health benefits }\end{array}$} \\
\hline $\begin{array}{l}\text { Food waste and } \\
\text { disposal }\end{array}$ & $\begin{array}{l}\text { Most losses are upstream, so better } \\
\text { processing, post-harvest, transportation } \\
\text { and market opportunities are critical. } \\
\text { Aflatoxins may be a key threat, and } \\
\text { should be considered for prevention } \\
\text { strategies }\end{array}$ & $\begin{array}{l}\text { Most losses are upstream, and in Asia } \\
\text { particularly in cereals and vegetables. } \\
\text { Better processing, post-harvest and } \\
\text { transportation opportunities are critical }\end{array}$ & \multicolumn{2}{|c|}{$\begin{array}{l}\text { In high-income countries, most losses are downstream, largely at the retail and consumer } \\
\text { level, involving fundamentally different challenges, mostly focused on behavior change } \\
\text { with some technological opportunities. Changing retail stocking and sourcing, } \\
\text { consumer acceptance of different quality products, better consumer planning and } \\
\text { preparation, and food preservation technologies can reduce waste and save consumers } \\
\text { money }\end{array}$} \\
\hline
\end{tabular}


Table 2. Adaptation co-benefits and system-level implications of mitigation opportunities. Drawing upon mitigation opportunities described in Table 1, adaptation co-benefits and system-level impacts are detailed below (Niles et al., 2017)

\begin{tabular}{|c|c|c|}
\hline \multirow{2}{*}{$\begin{array}{l}\text { Food system } \\
\text { component }\end{array}$} & \multicolumn{2}{|c|}{ Implications } \\
\hline & Adaptation co-benefits & System-level \\
\hline $\begin{array}{l}\text { Processing and } \\
\text { transportation }\end{array}$ & $\begin{array}{l}\text { Cold-chain expansion can help minimize food safety concerns } \\
\text { with warming temperatures (James and James, 2010) }\end{array}$ & $\begin{array}{l}\text { Cold-chain expansion will provide opportunities to minimize } \\
\text { food waste, increase nutrition and improve food safety, but } \\
\text { with costs to emissions. Demand side changes (e.g., demand } \\
\text { for processed foods, frozen foods, out of season produce, } \\
\text { etc.) could drive further growth in emissions from food } \\
\text { transport and processing (Heard and Miller, 2016) }\end{array}$ \\
\hline $\begin{array}{l}\text { Food waste and } \\
\text { disposal }\end{array}$ & $\begin{array}{l}\text { Increased access to post-harvest technologies including } \\
\text { cold-chain refrigeration will raise food availability in the } \\
\text { future under warmer conditions, but potentially raise } \\
\text { emissions (James and James, 2013) }\end{array}$ & $\begin{array}{l}\text { Food waste reductions are complex and involve the entire } \\
\text { system; for example, benefits for food security from reducing } \\
\text { food waste are not automatic. Downstream food waste } \\
\text { reductions could minimize agricultural land expansion and } \\
\text { reduce other environmental impacts (FAO, 2011a) }\end{array}$ \\
\hline
\end{tabular}

critical to explore opportunities to mitigate and adapt to CC both within various components and actors interacting within a food system, and across its parts. To facilitate this approach, we highlight key sources of GHG emissions and mitigation opportunities within different stages of the food system (Fig. 1), their relevance across varying country contexts (Table 1), and the potential adaptation co-benefits and food system-level implications of such strategies (Table 2).

\section{Pre-production}

Pre-production emissions generally result from the manufacture and distribution of agricultural inputs such as synthetic fertilizers and biocides (e.g., herbicides, pesticides, fungicides), as well as concentrates, supplements or antibiotics for livestock systems. The production of synthetic fertilizer is a significant source of GHG emissions, especially when it relies on coal (Vermeulen et al., 2012) and global fertilizer use has increased $233 \%$ between 1970 and 2010 (Smith et al., 2014). Mitigation strategies for preproduction include opportunities to increase the efficiency of input production systems, shift toward renewable or less GHG-intensive energy sources for its production, or shift toward more sustainable agricultural inputs required for agroecological practices (which would occur in the production phase). In high- and many middle-income countries, shifting away from high input use will be necessary to reduce GHGs, especially in areas of overapplication (Vitousek et al., 2009). In many lowincome countries, the addition of agricultural inputs could have significant benefits for food security (Vitousek et al., 2009; Rockström et al., 2017a, b) and help minimize agricultural land expansion and associated GHG emissions, through appropriate natural resource governance (Byerlee et al., 2014) and sustainable efficiencies. Opportunities for economically efficient agroecological alternatives to manufactured inputs include using organic sources of fertilizer such as manure or leguminous crops, crop rotations, companion plantings (Altieri et al., 2015), push-pull cropping strategies (Khan et al., 2014) and/or integrated pest and weed management (West and Post, 2002; Eagle et al., 2012).

\section{Production}

We divide this section into three kinds of production to better demonstrate how existing research differs across these systems.

\section{Cereals, grains and staple crops}

Significant reviews have explored the myriad opportunities to reduce yield scaled net emissions in cropping systems, with a strong focus on nitrous oxide emissions resulting from soil management (e.g., Eagle et al., 2012; Montes et al., 2013; Mangalassery et al., 2015; Di and Cameron, 2016; Thapa et al., 2016). Relevant strategies include: crop breeding for increased yield and/or adaptation to future CC impacts; fertilizer and input management including reduced application rates, increased efficiency, timing, fertilizer type, and application methods of manure and fertilizers (e.g., injection); cover crops; nitrification and urease inhibitors; increases in perennial crops; organic production; reduced or minimal tillage, crop rotation, water use efficiency and crop diversification. Additional research also suggests cropping systems could be critical for increasing soil carbon sequestration, with agricultural practices having the potential to sequester between 
1.3 and 8.0 $\mathrm{Pg} \mathrm{CO}_{2} \mathrm{eq} \mathrm{yr}^{-1}$ (Sommer and Bossio, 2014; Paustian et al., 2016)

Horticulture (fruit, vegetable, perennials)

Very few reviews exist for horticulture climate mitigation, a clear need for future research. Many noted strategies include: soil amendments, crop residue removal, cover crops, organic production, water use efficiency and improved drainage and compaction prevention in tree crops, many of which may also be relevant for other cropping systems (Aguilera et al., 2013; Congreves and Van Eerd, 2015; Rezaei Rashti et al., 2015; Swarts et al., 2016; Niles et al., 2017).

\section{Livestock/animal systems}

Livestock mitigation has been the subject of many reviews (e.g., (Thornton et al., 2009; Hristov et al., 2013; Montes et al., 2013; Global Research Alliance, 2014; Knapp et al., 2014). Focus has been largely on ruminant animals, due to their enteric fermentation emissions. Strategies generally focus on improving feed conversion efficiency (e.g., improved pasture quality, forage processing and digestibility, concentrates), controlling enteric emissions (e.g., feeding of edible oils, ionophores, vaccines, animal genetics), improving manure management (e.g., methane digesters, storage time, manure covers), grazing management (e.g., intensive grazing, reduced grazing in wet conditions, soil carbon sequestration), silvopasture and incorporation of woody plants and trees, and optimizing animal health (vaccines, animal genetics, heat stress prevention, access to veterinary care). Mitigation opportunities also exist in monogastric systems, particularly around manure management.

\section{Post-production manufacturing, processing and transportation}

Globalization and demand for processed foods may likely increase emissions from this portion of the food system (Vermeulen et al., 2012). Post-production activities including food processing, packaging, distribution (transport) and the cold chain (i.e., unbroken refrigeration throughout the supply chain for many products) contribute to GHG emissions, though the extent varies by country. While not exclusively, most mitigation opportunities in this component of the food system come from reducing demand for fossil energy sources and lowering emission intensities of both electricity generation and transport fuels.

\section{Processing}

In its most basic sense, food processing involves converting foods from one form to another in order to improve their stability and storability, their bioavailability and nutrition, and/or their desirability by the end user. Industrial food processes have traditionally been designed with the assumption of abundant material and energy resources (van der Goot et al., 2016). As a result, many are energy intensive; among the most intensive processes are oilseed and wet corn milling and refining [e.g., soy oil, high fructose corn syrup (Wang, 2013)], water removal, and food safety practices including sterilization and pasteurization. Wang suggests that a $25-34 \%$ energy savings in the British food processing industry is possible through technically feasible and economically practical improvements (Wang, 2013). Other authors call for a more fundamental redesign of food processing, away from highly refined, pure ingredients and toward mildly fractionated, complex and diverse 'functional fractions' (van der Goot et al., 2016).

\section{Refrigeration}

Refrigeration is another critical aspect of post-production GHG emissions. Around $40 \%$ of all food produced requires refrigeration and $15 \%$ of the electricity consumed worldwide is used for refrigeration (James and James, 2013). With today's electricity generation methods, this results in notable GHG emissions; for example, roughly $2.4 \%$ of the United Kingdom's GHG emissions are from food refrigeration (Garnett, 2007). Thus, utilizing more efficient refrigeration systems and increasing the use of renewable energies are critically important mitigation strategies for food systems. Currently, $<10 \%$ of perishable foodstuffs are currently refrigerated worldwide (James and James, 2013). Crops in most locations have seasonality and thus require managed storage, often through refrigeration or freezing in order to provide year-round consumption. Trade-offs between storage and out-of-season production GHG emissions and food transport emissions can vary greatly by season, product and location, as well as production and transportation strategies. While some studies demonstrate that local food production could result in lower GHG emissions (Lampert et al., 2016; Rothwell et al., 2016), other studies show situations where imported food results in lower emissions (Milà i Canals et al., 2007; Ledgard et al., 2011). While ozone-depleting refrigerants have largely been phased out, popular replacements [e.g., hydrofluorocarbons (HFCs)] have global warming potentials sometimes thousands of times higher than $\mathrm{CO}_{2}$ (Zhang et al., 2011). Recent changes to the Montreal Protocol will require withdrawal of HFCs in the coming $30 \mathrm{yr}$ (Kigali Amendment, 2016), providing excellent opportunities to reduce cold-chain refrigerant GHG emissions. If cold-chain expansion is combined with improvements in energy efficiency, it is estimated that it could continue into new regions without increasing GHG emissions and possibly even reduce emissions, as food waste lessens (James and James, 2010).

\section{Transportation}

While food distribution may be an easily identifiable mitigation target, from a food systems perspective, it often proves to be a less significant contribution to GHG emissions than assumed, and trade-offs exist with both production and storage stages. In the US, direct distribution of foods (from farm or production facility to retail stores) represented only $4 \%$ of the total greenhouse gas emissions of food, with indirect transportation (e.g., delivery of fertilizer to farms) adding an additional 7\% (Weber and Matthews, 2008). Others have found that consumers driving more than $7 \mathrm{~km}$ in the UK to purchase organic vegetables is more GHG intensive than the cold chain, transportation and storage of regionally produced vegetables delivered to a consumer directly (Coley et al., 2009). Opportunities to reduce transportation emissions are largely driven by either increased efficiencies or mode shifts, e.g., from road to rail. Refrigeration can also be a notable component of the food transportation system. Mobile refrigeration systems, especially in trucks, are commonly oversized and driven by auxiliary diesel engines, and can result in GHG emissions up to $140 \%$ of non-refrigerated trucks (Tassou et al., 2009). Thus, efforts to increase refrigeration efficiencies in transport vehicles are also an important strategy for reducing transportation emissions.

\section{Consumption}

Assessing the role of diets and food consumption patterns on CC is a growing research area (Nemecek et al., 2016), as diets 
consistently shift toward increased consumption of animal products, processed and packaged foods, lower micronutrient densities and greater energy intake in general (Pradhan et al., 2013; Tilman and Clark, 2014). Diet shifts-the 'nutritional transition'-are increasingly common as more countries shift toward more western-style diets (Popkin, 2001; Popkin et al., 2012). Since diet has the potential to be a significant portion of an individual's contribution toward GHG emissions (Macdiarmid, 2013), some studies have suggested that managing diets and demandside approaches may be more effective than technical agricultural mitigation options in reducing global emissions (Popp et al., 2010; Smith et al., 2013; Bajzelj et al., 2014). These mitigation options may be especially relevant to high-income countries where diets with high GHG emission profiles are more common, while lowand middle-income countries are often focused on ensuring food and nutrition security.

\section{Household storage and utilization}

A 2008 estimate placed the total number of domestic refrigerators worldwide at about one billion, twice as many as $12 \mathrm{yr}$ prior (Coulomb, 2008). The expansion of the cold chain into developing economies certainly means increased energy consumption at the consumer stages of the food system, but its net impact on GHG emissions for food systems as a whole is complex and uncertain (Heard and Miller, 2016). Estimates suggest that household refrigeration represents upwards of $17 \%$ of the total energy used by the US food system (Heller and Keoleian, 2003); appliance efficiency gains have been countered by growing refrigerator size and increased prevalence of second refrigerators (Kim et al., 2006). The addition of household refrigeration in developing economy food systems has the potential to decrease spoilage, improve food safety, diversify food choices and may lead to reduced food waste while improving nutritional outcomes. But it can also have indirect effects such as increased access, and likely greater consumption, of meat, dairy and prepackaged or frozen ready-made foods; shifts to larger, supermarket-style shopping patterns; and may in fact result in greater food waste if changes in consumer purchasing patterns facilitate overbuying (Heard and Miller, 2016). As Heard and Miller discuss, the balance of these factors on food system environmental impacts is challenging to assess and requires further study and evaluation.

\section{Processed foods}

Reducing consumption of processed and ultra-processed foods could help minimize emissions associated with their processing, packaging and transportation (van Dooren et al., 2014; Green et al., 2015). At least two recent studies found that ready-to-eat meals had much higher energy and GHG emissions compared with using fresh ingredients (Schmidt Rivera et al., 2014; Hanssen et al., 2017). As well, GHG emissions for the creation of bagged salads is largely due to both the agricultural phase and the use of water and energy in the processing phase (Fusi et al., 2016). However, efforts to minimize processed foods should balance potential benefits, such as contributions to nutrition and potential to reduce food waste as well as the balancing of seasonal supply and demand (Weaver et al., 2014).

\section{Balancing energy intake and individual metabolic demands}

As higher calorie diets become more prevalent, evidence grows that diets that exceed individual metabolic demands can result in greater environmental impact (van Dooren et al., 2014; Nelson et al., 2016). Avoiding energy consumption beyond individual needs could reduce GHG emissions up to $11 \%$ (Vieux et al., 2012). Further, some evidence suggests that a significant portion of additional calories (up to $39 \%$ in the average Australian diet, e.g.) come from discretionary foods including alcohol, candy and baked goods, which, if reduced, could allow for greater intake of vegetables, dairy and grain providing health benefits (Hendrie et al., 2016). Thus, reducing discretionary food to meet and not exceed metabolic demands could have both GHG emission benefits and potential health gains.

\section{Animal products}

A large body of recent work exploring the GHG emissions of different diet types typically highlights animal-based foods as a priority. Diets higher in animal products are associated with greater GHG emissions (González et al., 2011; Bajzelj et al., 2014; Abbade, 2015) and animal-based foods are the largest portion of GHG emissions in a typical diet (Heller and Keoleian, 2015; Monsivais et al., 2015; Hendrie et al., 2016; Clune et al., 2017; Hanssen et al., 2017; Vetter et al., 2017). Opportunities to reduce GHG emissions, particularly in economies with high levels of meat consumption, have focused on switching to different types of meat and animal products, low-animal or substantially reduced animal product consumption, for example, through Mediterranean, vegetarian or vegan diets. Beef production results in roughly five times the GHG emissions per calorie of nonruminant animal food sources like poultry, pork, dairy and eggs (Eshel et al., 2014). Switching to less GHG-intensive animal protein is an opportunity to reduce GHG emissions, with partial substitution of red meat with pork or chicken offering between a 9\% (Scarborough et al., 2012) and 19\% reduction in GHGs (Hoolohan et al., 2013) and full substitution up to $40 \%$ (Scarborough et al., 2014; Westhoek et al., 2014; Sabaté et al., 2015).

Shifting from animal products toward plant-based foods likely offers more significant reductions to dietary GHG emissions. Studies range in their estimates with reductions of $22 \%$ (vegetarian) or $26 \%$ (vegan) (Berners-Lee et al., 2012) to potential reductions by 2050 of up to $70 \%$ over current diets (Springmann et al., 2016). The inclusion of eggs and dairy (vegetarian) or no animal products at all (vegan) has resulted in varying outcomes for GHG emissions, given these products. For example, cheese has been found to have higher dietary emissions than eggs and poultry; conversely milk, cream and yoghurt have much lower dietary GHG emissions than eggs, poultry and even many vegetables and grains (Hamerschlag, 2011; Scarborough et al., 2014). Related research exploring diets such as the Mediterranean or New Nordic diets have found that these reduced GHG emissions compared with traditional Western European diets (Saxe et al., 2013; Pairotti et al., 2015), though vegetarian diets have the potential to reduce GHG emissions more (Pairotti et al., 2015; Tilman and Clark, 2015).

Considering nutritional outcomes is critical in evaluating potential dietary shifts (Vetter et al., 2017). Potential micronutrient shifts have been explored (Temme et al., 2015; Payne et al., 2016), as well as the implications of recommending dietary shifts in low-income and middle-income economies where food insecurity and hunger may still be prevalent (Garnett, 2011). Diet shifts away from animal products, especially red meat, offer mortality risk benefits (Westhoek et al., 2014; Aleksandrowicz et al., 2016) and there are general synergies between diets low in GHGs and health benefits (Tilman and Clark, 2014; Gephart et al., 2016; Irz et al., 2016), though this is not universal [sugar, e.g., has a low GHG impact but negative health consequences 
(Briggs et al., 2016)]. However, there has been significantly less research on dietary shifts and GHG emission reductions in lowand middle-income countries (Jones et al., 2016), despite the nutritional transition many are undergoing. Overall, existing research indicates that dietary shifts toward non-ruminant protein sources will provide reductions in GHG emissions, though the extent of these reductions is variable depending on the protein replacement.

\section{Loss, waste and disposal}

Food loss (pre-consumer), waste (consumer-level) and disposal (post-consumer) represent a significant source of GHG emissions since up to one-third of all food produced is lost or wasted globally each year (FAO, 2011a), and food waste tripled between 1960 and 2011 (Porter and Reay, 2016). The FAO estimates that if food waste were a country, it would be the third largest emitter of GHG emissions in the world (FAO, 2013). The food groups where losses matter most to GHG emissions and other environmental impacts are cereals, vegetables and meat (FAO, 2013).

In low-income countries, the majority of food is lost and occurs at the production, post-harvest and processing/transportation phases. These losses are often due to a lack of infrastructure including cold-chain refrigeration, processing facilities and reliable transportation to bring crops to market. As a result, crops may spoil before they can be fully utilized (FAO, 2011a). A lack of available drying technologies or improper storage can also contribute to losses due to aflatoxins, poisonous carcinogens produced by molds in staple crops under high moisture, high temperature conditions (PACA, 2013). Opportunities to minimize food loss and waste in low-income countries include the expansion of transportation infrastructure, processing and preservation infrastructure including the cold chain, drying technologies and increased market opportunities (FAO, 2011a), though many of these may result in increased use of energy or resources. Nevertheless, given that agricultural production is the majority of GHG emissions during the production of most food (Vermeulen et al., 2012), efforts to minimize loss and waste, even at the expansion of emission sources from other aspects of the food system, would likely result in overall benefits.

Conversely, in high-income countries, most food is wasted at the retail and consumption levels (FAO, 2013; Blanke, 2015). Opportunities to reduce food waste in retail include changing consumer perceptions about food appearances, reducing overstocking, reducing portion sizes in restaurants, utilizing packaging and processing technologies that help keep food fresh for longer, and clarifying the meaning of sell-by and use-by dates for consumers (Blanke, 2015; Schanes et al., 2016; Wilson et al., 2017). Prevention of consumer food waste must consider complex human behaviors (Quested et al., 2013) but might involve consumer acceptance of 'ugly' produce, increased planning and preparation for cooking, better storage techniques and food sharing (Blanke, 2015).

In addition to the impacts associated with producing food that is not eaten, food disposal in landfills is also a source of methane emissions as food decomposes anaerobically. Globally, landfills are the third largest source of methane emissions (Global Methane Initiative, no date), though not all is attributable to food waste. Opportunities to reduce methane emissions from landfills include diverting food waste for animal feed, and compost and employing methane capture technologies, which can also be used to generate electricity (Krause et al., 2016).

\section{Implications for action}

\section{Policy and funding mechanisms}

There are multiple opportunities to reduce GHG emissions throughout the food system, although these vary with country contexts. Policies and funding will be critical catalysts for positive change. While high-income and low-income countries face different present-day challenges, experts contend that there is a global need for contraction and a convergence toward universal access to nutritious, low-emissions diets (Rockström et al., 2017a). Reductions in emissions from food systems will require actions from all value chain participants, including consumers, manufacturers, farmers and input suppliers.

Public policy will play a major role in driving change toward a lower food system GHG footprint in balance with other goals for food systems, such as health, jobs, incomes, biodiversity and gender equality. As governments recognize the opportunities with interlinked nutritional and environmental functions of food systems as well as the urgency for action, policy discourse is shifting from a focus on voluntary measures-such as consumer education, purchasing guidelines, commodity roundtables and good practice guidelines (Foresight, 2011) - to other complementary actions such as stronger regulatory and fiscal incentives, including food taxes, particularly in industrialized countries, mandatory industry standards, renewable energy subsidies and controls on land use change (De Pinto et al., 2016; Mason and Lang, 2017; Springmann et al., 2017). Further integration of sustainability criteria in food dietary guidelines could also be a driver for changing dietary patterns toward healthy, sustainable GHG diets (Fischer and Garnett, 2016). However, this is currently only happening in four countries (Brazil, Germany, Qatar and Sweden) with recommendations in countries such as the US unsuccessful thus far (Dietary Guidelines Advisory Committee, 2015; Merrigan et al., 2015).

A shortfall in dedicated public and private finance to catalyze the necessary transition remains a critical barrier-for example, the US $\$ 2.5$ trillion cost for agricultural mitigation estimated by 50 parties to the Paris Agreement is far in excess of globally available finance (Richards et al., 2016). Climate finance offers opportunities to achieve mitigation across a global context and refers to the 'financial flows mobilized by high-income country governments and private entities that support CC mitigation and adaptation in low- and middle-income countries (Stadelmann et al., 2013). The international community aims to mobilize at least US $\$ 100$ billion per year for mitigation and adaption in lowand middle-income countries. Unfortunately, only a small portion of global climate finance ( $\$ 6-8$ billion of $\$ 391$ billion in 2015 ) is allocated to agriculture, and it is unclear how much can be traced directly to climate-smart agriculture and climatefriendly food systems.

Climate measures are much more likely to succeed if they not only aim at reducing emissions or creating climate resilience, but also integrate broader domestic development objectives, such as poverty reduction, food security, energy security, energy access or transportation (Jakob et al., 2014). We argue that it is important to incorporate food systems thinking and related GHG mitigation and adaptation impacts into the decision-making process, which are adapted to the socio-institutional context (Vignola et al., 2017), as policies are developed and investments are mobilized for achieving a variety of other sustainable development goals. A systems approach on the whole food value chain is necessary for assessing current climate finance and re-directing 
investments in climate-friendly food systems. To support decision-making, stakeholders are considering the potential utility of putting an explicit price on carbon emissions to help ensure that analysis of policy options and climate mitigation actions identify the most cost-effective mitigation efforts across the economy (Steckel et al., 2017). To actually develop carbon pricing schemes, however, would require significant additional research and work to develop schemes appropriate for national contexts and priorities. Global Climate Fund and other multilateral funds and the growing green bonds market could be utilized to generate low cost capital and catalyze broader investments for climate-friendly food systems.

\section{Research needs}

The recent growth in food system and climate research is timely and laudable. Yet there remains much additional work, particularly in low-income countries and across multiple components of the food system. For example, although the greatest increases in GHG emissions from food loss and waste in recent decades are coming from low- and middle-income countries (Porter et al., 2016), barely any empirical research explores how to overcome these challenges (Nemecek et al., 2016; Porter et al., 2016). Further, the rapid dietary shifts in low- and especially middle-income countries toward high GHG diets (Clonan et al., 2016) has not resulted in a commensurate increase in research on assessing dietary changes and their climate implications in these contexts, and the majority of available studies focus on highincome countries (Jones et al., 2016). Understanding the myriad benefits and impacts of cold-chain expansion, including unintended feedback and rebound effects, is also a priority research topic. Other research priorities we have identified include improved post-harvest management (food storage, transformation, handling and processing) to reduce food contamination and losses (Tirado et al., 2013, 2015), as well as an increased focus on mitigation opportunities in horticulture. Given quickly evolving contexts, we argue that it is critical to increase food systems and CC research in low- and middle-income countries across these, and likely many other, topics.

\section{Conclusion}

Our global and local food systems need urgent action to reduce GHG emissions in ways that enable resilience and sustainability. Though an extensive body of research explores how we can mitigate and adapt to CC in agriculture, substantially less work has focused across the food system to explore opportunities for climate mitigation and adaptation more comprehensively. Here, we highlight some of the key strategies across the food system to mitigate emissions, and their applicability in varying country contexts. We have illustrated ways in which certain mitigation options in specific food system components could have profound impacts on other areas and also potentially offer adaptation co-benefits. However, the majority of existing peer-reviewed literature does not examine CC in food systems through this lens. Thus, future systems-level research is critical to assess connections to other sustainable development goals and ensure that mitigation of food system emissions does not have untold impacts in other sectors. Conducting this work in low- and middle-income countries is especially important as the policies and investments they put into place today will have a profound impact on their food systems, including its mitigation and adaptation capacity.
While many policy and funding mechanisms have been proposed, far fewer have been implemented to meet the need/aim of sustainable food systems in a changing climate. Such efforts can be informed by empirical research, including reviews such as these but will ultimately require political will and clear, equitable and resilient funding mechanisms. Increased efforts to implement research, policies and funding mechanisms simultaneously are necessary to achieve climate mitigation and adaptation goals now and into the future inside a sustainable food system development.

Acknowledgements. The authors thank Mil Duncan, Carsey School of Public Policy, University of New Hampshire (USA) for her review of literature on climate change and agricultural production. The authors also thank Advisory Committee members of Meridian Institute's Climate Change and Food Systems project who provided input on the scope and contents of the draft report Climate Change and Food Systems: Assessing Impacts and Opportunities. Advisory Committee members include: Kofi Boa, Center for No-Till Agriculture (Ghana); Timothy Griffin, Friedman School, Tufts University (USA); Tony LaViña, Ateneo de Manila University, University of the Philippines, De La Salle College of Law, Philippine Judicial Academy (Philippines); Alexander Müeller, The Economics of Ecosystems and Biodiversity for Agriculture and Food (TEEBAgriFood) (Germany); Ruth Richardson, Global Alliance for the Future of Food (Canada); Maria Sanz-Sánchez, BC3 Basque Centre for Climate Change (Spain); Whendee Silver, UC Berkeley (USA); Pete Smith, University of Aberdeen (Scotland); and Charlotte Streck, Climate Focus (USA). The authors thank the Global Alliance for the Future of Food for their generous support.

\section{References}

Abbade EB (2015) Environmental impacts of food supply and obesogenic severity worldwide. British Food Journal, Emerald 117(12), 2863-2879. doi: 10.1108/BFJ-12-2014-0404.

Aguilera E, Lassaletta L, Gattinger A and Gimeno BS (2013) Managing soil carbon for climate change mitigation and adaptation in Mediterranean cropping systems: a meta-analysis. Agriculture, Ecosystems \& Environment 168, 25-36. doi: 10.1016/j.agee.2013.02.003.

Aleksandrowicz L, Green R, Joy EJM, Smith P and Haines A (2016) The impacts of dietary change on greenhouse gas emissions, land use, water use, and health: a systematic review. PLoS ONE, Public Library of Science 11(11), e0165797. doi: 10.1371\%2Fjournal.pone.0165797.

Altieri MA, Nicholls CI, Henao A and Lana MA (2015) Agroecology and the design of climate change-resilient farming systems. Agronomy for Sustainable Development 35(3), 869-890. doi: 10.1007/s13593-015-0285-2.

Bajzelj B, Richards KS, Allwood JM, Smith P, Dennis JS, Curmi E and Gilligan CA (2014) Importance of food-demand management for climate mitigation. Nature Climate Change, Nature Publishing Group 4(10), 924 929. doi: $10.1038 /$ nclimate2353.

Berners-Lee M, Hoolohan C, Cammack H and Hewitt CN (2012) The relative greenhouse gas impacts of realistic dietary choices. Energy Policy 43, 184-190. doi: 10.1016/j.enpol.2011.12.054.

Blanke M (2015) Challenges of reducing fresh produce waste in Europe-from farm to fork. Agriculture 5(3), 389-399. doi: 10.3390/agriculture5030389.

Briggs ADM, Kehlbacher A, Tiffin R and Scarborough P (2016) Simulating the impact on health of internalising the cost of carbon in food prices combined with a tax on sugar-sweetened beverages. BMC Public Health 16(1), 107. doi: 10.1186/s12889-016-2723-8.

Brown ME, Antle JM, Backlund P, Carr EG, Easterling WE, Walsh MK, Ammann C, Attavanich W, Barrett CB, Bellemare MF, Dancheck V, Funk C, Grace K, Ingram JSI, Jiang H, Maletta H, Mata T, Murray A, Ngugi M, Ojima D, O'Neill B and Tebaldi C (2015) Climate Change, Global Food Security, and the U.S. Food System. Report. Washington, DC: USDA Technical Document. doi: 10.7930/J0862DC7.

Byerlee D, Stevenson J and Villoria N (2014) Does intensification slow crop land expansion or encourage deforestation? Global Food Security 3(2), 9298. doi: 10.1016/j.gfs.2014.04.001. 
Challinor AJ, Watson J, Lobell DB, Howden SM, Smith DR and Chhetri N (2014) A meta-analysis of crop yield under climate change and adaptation. Nature Climate Change, Nature Publishing Group 4(4), 287-291. doi: 10.1038/nclimate2153.

Clonan A, Roberts KE and Holdsworth M (2016) Socioeconomic and demographic drivers of red and processed meat consumption: implications for health and environmental sustainability. Proceedings of the Nutrition Society, 2016/03/29, Cambridge University Press 75(3), 367-373. doi: $10.1017 /$ S0029665116000100.

Clune S, Crossin E and Verghese K (2017) Systematic review of greenhouse gas emissions for different fresh food categories. Journal of Cleaner Production 140(Part), 766-783. doi: 10.1016/j.jclepro.2016.04.082.

Coley D, Howard M and Winter M (2009) Local food, food miles and carbon emissions: a comparison of farm shop and mass distribution approaches. Food Policy 34(2), 150.

Congreves KA and Van Eerd LL (2015) Nitrogen cycling and management in intensive horticultural systems. Nutrient Cycling in Agroecosystems 102(3), 299-318. doi: 10.1007/s10705-015-9704-7.

Coulomb D (2008) Refrigeration and cold chain serving the global food industry and creating a better future: two key IIR challenges for improved health and environment. Trends in Food Science \& Technology 19(8), 413-417. doi: 10.1016/j.tifs.2008.03.006.

De Pinto A, Li M, Haruna A, Hyman GG, Martinez MAL, Creamer B, Kwon H-Y, Garcia JBV, Tapasco J and Martinez JD (2016) Low emission development strategies in agriculture. An agriculture, forestry, and other land uses (AFOLU) perspective. World Development 87, 180-203. doi: 10.1016/j.worlddev.2016.06.013.

Di HJ and Cameron KC (2016) Inhibition of nitrification to mitigate nitrate leaching and nitrous oxide emissions in grazed grassland: a review. Journal of Soils and Sediments 16(5), 1401-1420. doi: 10.1007/s11368-016-1403-8.

Dietary Guidelines Advisory Committee (2015) Scientific Report of the 2015 Dietary Guidelines Advisory Committee. Available at https://health. gov/dietaryguidelines/2015-scientific-report/PDFs/Scientific-Report-of-the2015-Dietary-Guidelines-Advisory-Committee.pdf.

Eagle AJ, Olander LP, Henry K, Haugen-kozyra K, Millar $\mathrm{N}$ and Robertston G (2012) Greenhouse Gas Mitigation Potential of Agricultural Land Management in the United States. A Synthesis of the Literature. Durham, NC. Available at https://nicholasinstitute.duke.edu/sites/default/ files/publications/ni_r_10-04_3rd_edition.pdf.

Eshel G, Shepon A, Makov T and Milo R (2014) Land, irrigation water, greenhouse gas, and reactive nitrogen burdens of meat, eggs, and dairy production in the United States. Proceedings of the National Academy of Sciences 111(33), 11996-12001. doi: 10.1073/pnas.1402183111.

FAO (2011a) Food Losses, Global Food Waste-Extent, Causes and Prevention. Rome: Food and Agriculture Organization of the United Nations.

FAO (2011b) World Livestock 2011- Livestock in Food Security. Rome: Food and Agriculture Organization.

FAO (2013) Food Wastage Footprint Impact on Natural Resources: A Summary Report. Rome. Available at http://www.fao.org/docrep/018/i3347e/i3347e.pdf.

Fischer CG and Garnett T (2016) Plates, pyramids, planet: developments in national healthy and sustainable dietary guidelines: a state of play assessment.

Foley JA, Ramankutty N, Brauman KA, Cassidy ES, Gerber JS, Johnston M, Mueller ND, O'Connell C, Ray DK and West PC (2011) Solutions for a cultivated planet. Nature 478(7369), 337-342.

Foresight (2011) The Future of Food and Farming. London. Available at http:// www.eracaps.org/sites/default/files/content/foresight_report.pdf.

Fusi A, Castellani V, Bacenetti J, Cocetta G, Fiala M and Guidetti R (2016) The environmental impact of the production of fresh cut salad: a case study in Italy. The International Journal of Life Cycle Assessment 21(2), 162-175. doi: 10.1007/s11367-015-1019-z.

Garnett (2007) Food refrigeration: what is the contribution to greenhouse gas emissions and how might emissions be reduced.

Garnett T (2011) Where are the best opportunities for reducing greenhouse gas emissions in the food system (including the food chain)? Food Policy 36(suppl.), S23-S32. doi: 10.1016/j.foodpol.2010.10.010.

Gephart JA, Davis KF, Emery KA, Leach AM, Galloway JN and Pace ML (2016) The environmental cost of subsistence: optimizing diets to minimize footprints. Science of the Total Environment 553, 120-127. doi: 10.1016/ j.scitotenv.2016.02.050.

Global Methane Initiative (no date) Global Methane Emissions and Mitigation Opportunities. Available at http://www.globalmethane.org/documents/analysis_fs_en.pdf.

Global Research Alliance (2014) Reducing greenhouse gas emissions from livestock: best practice and emerging options. Available at http://globalresearchalliance.org/wp-content/uploads/2014/12/LRG-SAI-Livestock-Mitigation web2.pdf.

González AD, Frostell B and Carlsson-Kanyama A (2011) Protein efficiency per unit energy and per unit greenhouse gas emissions: potential contribution of diet choices to climate change mitigation. Food Policy 36(5), 562570. doi: 10.1016/j.foodpol.2011.07.003.

Green R, Milner J, Dangour AD, Haines A, Chalabi Z, Markandya A, Spadaro J and Wilkinson P (2015) The potential to reduce greenhouse gas emissions in the UK through healthy and realistic dietary change. Climatic Change 129(1), 253-265. doi: 10.1007/s10584-015-1329-y.

Hamerschlag K (2011) A meat eater's guide to climate change and health: what you eat matters. Available at http://static.ewg.org/reports/2011/meateaters/ pdf/report_ewg_meat_eaters_guide_to_health_and_climate_2011.pdf?_ga $=2$. 161131901.1145852566.1506710799-849931389.1504634432.

Hanssen OJ, Vold M, Schakenda V, Tufte P-A, Møller H, Olsen NV and Skaret J (2017) Environmental profile, packaging intensity and food waste generation for three types of dinner meals. Journal of Cleaner Production 142(Part), 395-402. doi: 10.1016/j.jclepro.2015.12.012.

Heard BR and Miller SA (2016) Critical research needed to examine the environmental impacts of expanded refrigeration on the food system. Environmental Science \& Technology, American Chemical Society 50(22), 12060-12071. doi: 10.1021/acs.est.6b02740.

Heller MC and Keoleian GA (2003) Assessing the sustainability of the US food system: a life cycle perspective. Agricultural Systems 76(3), 1007.

Heller MC and Keoleian GA (2015) Greenhouse gas emission estimates of U.S. dietary choices and food loss. Journal of Industrial Ecology 19(3), 391-401. doi: 10.1111/jiec.12174.

Hendrie AG, Baird D, Ridoutt B, Hadjikakou M and Noakes M (2016) Overconsumption of energy and excessive discretionary food intake inflates dietary greenhouse gas emissions in Australia. Nutrients 8(11), 690. doi: $10.3390 /$ nu8110690.

HLPE (2014) Food Losses and Waste in the Context of Sustainable Food Systems. Rome. Available at http://www.fao.org/3/a-i3901e.pdf.

Hoolohan C, Berners-Lee M, McKinstry-West J and Hewitt CN (2013) Mitigating the greenhouse gas emissions embodied in food through realistic consumer choices. Energy Policy 63, 1065-1074. doi: 10.1016/j.enpol.2013.09.046.

Hristov AN, Ott T, Tricarico J, Rotz A, Waghorn G, Adesogan A, Dijkstra J, Montes F, Oh J, Kebreab E, Oosting SJ, Gerber PJ, Henderson B, Makkar HPS and Firkins JL (2013) SPECIAL TOPICSmitigation of methane and nitrous oxide emissions from animal operations: III. A review of animal management mitigation options1. Journal of Animal Science, Madison, WI: American Society of Animal Science 91, 5095-5113. doi: $10.2527 /$ jas.2013-6585.

Irz X, Leroy P, Réquillart V and Soler L-G (2016) Welfare and sustainability effects of dietary recommendations. Ecological Economics 130, 139-155. doi: 10.1016/j.ecolecon.2016.06.025.

Jakob M, Steckel JC, Klasen S, Lay J, Grunewald N, Martinez-Zarzoso I, Renner S and Edenhofer O (2014) Feasible mitigation actions in developing countries. Nature Climate Change, Nature Publishing Group, a division of Macmillan Publishers Limited. All Rights Reserved 4(11), 961-968. doi: $10.1038 /$ nclimate2370

James SJ and James C (2010) The food cold-chain and climate change. Food Research International, Elsevier Ltd 43(7), 1944-1956. doi: 10.1016/ j.foodres.2010.02.001.

James SJ and James C (2013) Sustainable cold chain. In Tiwari BK, Norton T and Holden NM (eds). Sustainable Food Processing. Chichester, UK: John Wiley \& Sons, Ltd, pp. 463-496. doi: 10.1002/9781118634301.ch19.

Jones AD, Hoey L, Blesh J, Miller L, Green A and Shapiro LF (2016) A systematic review of the measurement of sustainable diets. Advances in Nutrition: an International Review Journal 7(4), 641-664. doi: 10.3945/an.115.011015. 
Khan ZR, Midega CAO, Pittchar JO, Murage AW, Birkett MA, Bruce TJA and Pickett JA (2014) Achieving food security for one million sub-Saharan African poor through push-pull innovation by 2020. Philosophical Transactions of the Royal Society B: Biological Sciences 369(1639). Available at http://rstb.royalsocietypublishing.org/content/369/1639/20120284.abstract.

Kigali Amendment (2016) Available at http://conf.montreal-protocol.org/meeting/mop/mop-28/final-report/English/Kigali_Amendment-English.pdf.

Kim HC, Keoleian GA and Horie YA (2006) Optimal household refrigerator replacement policy for life cycle energy, greenhouse gas emissions, and cost. Energy Policy 34, 2310.

Knapp JR, Laur GL, Vadas PA, Weiss WP and Tricarico JM (2014) Invited review: enteric methane in dairy cattle production: quantifying the opportunities and impact of reducing emissions. Journal of Dairy Science, Elsevier 97(6), 3231-3261. doi: 10.3168/jds.2013-7234.

Krause MJ, Chickering G W, Townsend TG and Reinhart DR (2016) Critical review of the methane generation potential of municipal solid waste. Critical Reviews in Environmental Science and Technology, Taylor \& Francis 46(13), 1117-1182. doi: 10.1080/10643389.2016.1204812.

Lampert P, Soode E, Menrad K and Theuvsen L (2016) Distributing asparagus: a climate perspective considering producer and consumer aspects. Agroecology and Sustainable Food Systems, Taylor \& Francis 40(2), 169186. doi: $10.1080 / 21683565.2015 .1118718$.

Ledgard SF, Lieffering M, Coup D and O'Brien B (2011) Carbon footprinting of New Zealand lamb from the perspective of an exporting nation. Animal Frontiers, Madison, WI: American Society of Animal Science 1, 40-45. doi: 10.2527/af.2011-0010.

Lloyd SJ, Kovats RS and Chalabi Z (2011) Climate change, crop yields, and undernutrition: development of a model to quantify the impact of climate scenarios on child undernutrition. Environmental Health Perspectives 119, 1817-1823.

Macdiarmid JI (2013) Is a healthy diet an environmentally sustainable diet? Proceedings of the Nutrition Society, 2012/11/28, Cambridge University Press 72(1), 13-20. doi: 10.1017/S0029665112002893.

Mangalassery S, Sjögersten S, Sparkes DL and Mooney SJ (2015) Examining the potential for climate change mitigation from zero tillage. The Journal of Agricultural Science 153(7), 1151-1173.

Mason P and Lang T (2017) Sustainable Diets: How Ecological Nutrition Can Transform Consumption and the Food System, 1st edn. Oxon, UK and New York, NY: Routledge.

McDaniel MD, Tiemann LK and Grandy AS (2014) Does agricultural crop diversity enhance soil microbial biomass and organic matter dynamics? A meta-analysis. Ecological Applications, Ecological Society of America 24 (3), 560-570. doi: 10.1890/13-0616.1.

Merrigan K, Griffin T, Wilde P, Robien K, Goldberg J and Dietz W (2015) Designing a sustainable diet. Science 350(6257), 165 LP-165166. Available at http://science.sciencemag.org/content/350/6257/165.abstract.

Milà i Canals L, Cowell SJ, Sim S and Basson L (2007) Comparing domestic versus imported apples: a focus on energy use. Environmental Science and Pollution Research 14(5), 338-344.

Monsivais P, Scarborough P, Lloyd T, Mizdrak A, Luben R, Mulligan AA, Wareham NJ and Woodcock J (2015) Greater accordance with the dietary approaches to stop hypertension dietary pattern is associated with lower diet-related greenhouse gas production but higher dietary costs in the United Kingdom. The American Journal of Clinical Nutrition 102(1), 138-145. doi: 10.3945/ajcn.114.090639.

Montes F, Meinen R, Dell C, Rotz A, Hristov AN, Oh J, Waghorn G, Gerber PJ, Henderson B, Makkar HPS and Dijkstra J (2013) SPECIAL TOPICS-mitigation of methane and nitrous oxide emissions from animal operations: II. A review of manure management mitigation options1. Journal of Animal Science, Madison, WI: American Society of Animal Science 91, 5070-5094. doi: 10.2527/jas.2013-6584.

Myers SS, Zanobetti A, Kloog I, Huybers P, Leakey ADB, Bloom AJ, Carlisle E, Dietterich LH, Fitzgerald G, Hasegawa T, Holbrook NM, Nelson RL, Ottman MJ, Raboy V, Sakai H, Sartor KA, Schwartz J, Seneweera S, Tausz $\mathbf{M}$ and Usui $\mathbf{Y}$ (2014) Increasing $\mathrm{CO}_{2}$ threatens human nutrition. Nature, Nature Publishing Group 510(7503), 139-142. doi: $10.1038 /$ nature13179.
Nelson GC, Rosegrant MW, Koo J, Robertson R, Sulser T, Zhu T, Ringler C, Msangi S, Palazzo A, Batka M, Magalhaes M, Valmonte-Santos R, Ewing M and Lee D (2009) Climate Change: Impact on Agriculture and Costs of Adaptation. International Food Policy Research Institute. Available at http://www.ifpri.org/publication/climatechange-impact-agriculture-and-costs-adaptation.

Nelson ME, Hamm MW, Hu FB, Abrams SA and Griffin TS (2016) Alignment of healthy dietary patterns and environmental sustainability: a systematic review. Advances in Nutrition: an International Review Journal 7(6), 1005-1025. doi: 10.3945/an.116.012567.

Nemecek T, Jungbluth N, i Canals LM and Schenck R (2016) Environmental impacts of food consumption and nutrition: where are we and what is next? The International Journal of Life Cycle Assessment 21(5), 607-620. doi: 10.1007/s11367-016-1071-3.

Niles MT, Ahuja R, Esquivel J, Mango N, Duncan M, Heller M and Tirado C (2017) Climate Change and Food Systems: Assessing Impacts and Opportunities. Available at http://www.merid.org/climatechangefoodsystems.aspx.

PACA (2013) Aflatoxin Impacts and Potential Solutions in Agriculture, Trade, and Health. Available at http://www.aflatoxinpartnership.org/uploads/files/ AflatoxinImpactsPaper_0.pdf.

Pairotti MB, Cerutti AK, Martini F, Vesce E, Padovan D and Beltramo R (2015) Energy consumption and GHG emission of the Mediterranean diet: a systemic assessment using a hybrid LCA-IO method. Journal of Cleaner Production 103, 507-516. doi: 10.1016/j.jclepro.2013.12.082.

Paustian K, Lehmann J, Ogle S, Reay D, Robertson GP and Smith P (2016) Climate-smart soils. Nature, Nature Publishing Group, a division of Macmillan Publishers Limited. All Rights Reserved 532(7597), 49-57. doi: 10.1038/nature17174.

Payne CLR, Scarborough P and Cobiac L (2016) Do low-carbon-emission diets lead to higher nutritional quality and positive health outcomes? A systematic review of the literature. Public Health Nutrition, 2016/03/15, Cambridge University Press 19(14), 2654-2661. doi: 10.1017/S1368980016000495.

Popkin BM (2001) The nutrition transition and obesity in the developing world. The Journal of Nutrition 131(3), 871S-873S. Available at http://jn. nutrition.org/content/131/3/871S.abstract.

Popkin BM, Adair LS and Ng SW (2012) Global nutrition transition and the pandemic of obesity in developing countries. Nutrition Reviews 70, 3-21. doi: $10.1111 /$ j.1753-4887.2011.00456.x.

Popp A, Lotze-Campen H and Bodirsky B (2010) Food consumption, diet shifts and associated non- $\mathrm{CO} 2$ greenhouse gases from agricultural production. Global Environmental Change 20(3), 451-462. doi: 10.1016/ j.gloenvcha.2010.02.001.

Porter SD and Reay DS (2016) Addressing food supply chain and consumption inefficiencies: potential for climate change mitigation. Regional Environmental Change 16(8), 2279-2290. doi: 10.1007/s10113-015-0783-4.

Porter SD, Reay DS, Higgins P and Bomberg E (2016) A half-century of production-phase greenhouse gas emissions from food loss \& waste in the global food supply chain. Science of the Total Environment 571, 721729. doi: 10.1016/j.scitotenv.2016.07.041.

Pradhan P, Reusser DE and Kropp JP (2013) Embodied greenhouse gas emissions in diets. PLoS ONE, Public Library of Science 8(5), e62228. doi: $10.1371 \% 2$ Fjournal.pone.0062228.

Quested TE, Marsh E, Stunell D and Parry AD (2013) Spaghetti soup: the complex world of food waste behaviours. Resources, Conservation and Recycling 79, 43-51. doi: 10.1016/j.resconrec.2013.04.011.

Rezaei Rashti M, Wang W, Moody P, Chen C and Ghadiri H (2015) Fertiliser-induced nitrous oxide emissions from vegetable production in the world and the regulating factors: a review. Atmospheric Environment 112, 225-233. doi: 10.1016/j.atmosenv.2015.04.036.

Richards M, Bruun TB, Campbell B, Gregersen LE, Huyer S, Kuntze V, Madsen STN, Oldvig MB and Vasileiou I (2016) How countries plan to address agricultural adaptation and mitigation: An analysis of Intended Nationally Determined Contributions. CCAFS dataset version 1.2. Copenhagen, Denmark: CGIAR Research Program on Climate Change, Agriculture and Food Security (CCAFS).

Rippke U, Ramirez-Villegas J, Jarvis A, Vermeulen SJ, Parker L, Mer F, Diekkruger B, Challinor AJ and Howden M (2016) Timescales of 
transformational climate change adaptation in sub-Saharan African agriculture. Nature Climate Change, Nature Publishing Group 6(6), 605-609. doi: 10.1038/nclimate2947.

Rockström J, Stordalen GA and Horton R (2017a) Acting in the anthropocene: the EAT-Lancet commission. The Lancet, Elsevier 387(10036), 23642365. doi: 10.1016/S0140-6736(16)30681-X.

Rockström J, Williams J, Daily G, Noble A, Matthews N, Gordon L, Wetterstrand H, DeClerck F, Shah M, Steduto P, de Fraiture C, Hatibu N, Unver O, Bird J, Sibanda L and Smith J (2017b) Sustainable intensification of agriculture for human prosperity and global sustainability. Ambio 46(1), 4-17. doi: 10.1007/s13280-016-0793-6.

Rothwell A, Ridoutt B, Page G and Bellotti W (2016) Environmental performance of local food: trade-offs and implications for climate resilience in a developed city. Journal of Cleaner Production 114(suppl. C), 420430. doi: 10.1016/j.jclepro.2015.04.096.

Sabaté J, Sranacharoenpong K, Harwatt H, Wien M and Soret S (2015) The environmental cost of protein food choices. Public Health Nutrition, 2014/ 11/06, Cambridge University Press 18(11), 2067-2073. doi: 10.1017/ S1368980014002377.

Saxe H, Larsen TM and Mogensen L (2013) The global warming potential of two healthy Nordic diets compared with the average Danish diet. Climatic Change 116(2), 249-262. doi: 10.1007/s10584-012-0495-4.

Scarborough P, Allender S, Clarke D, Wickramasinghe $K$ and Rayner M (2012) Modelling the health impact of environmentally sustainable dietary scenarios in the UK. European Journal of Clinical Nutrition 66, 710-715. doi: 10.1038/ejcn.2012.34.

Scarborough P, Appleby PN, Mizdrak A, Briggs ADM, Travis RC, Bradbury KE and Key TJ (2014) Dietary greenhouse gas emissions of meat-eaters, fish-eaters, vegetarians and vegans in the UK. Climatic Change 125(2), 179-192. doi: 10.1007/s10584-014-1169-1.

Schanes K, Giljum S and Hertwich E (2016) Low carbon lifestyles: a framework to structure consumption strategies and options to reduce carbon footprints. Journal of Cleaner Production 139, 1033-1043. doi: 10.1016/ j.jclepro.2016.08.154.

Schmidt Rivera XC, Espinoza Orias N and Azapagic A (2014) Life cycle environmental impacts of convenience food: comparison of ready and home-made meals. Journal of Cleaner Production 73, 294.

Smith P, Haberl H, Popp A, Erb K, Lauk C, Harper R, Tubiello FN, de Siqueira Pinto A, Jafari M, Sohi S, Masera O, Böttcher H, Berndes G, Bustamante M, Ahammad H, Clark H, Dong H, Elsiddig EA, Mbow C, Ravindranath NH, Rice CW, Robledo Abad C, Romanovskaya A, Sperling F, Herrero M, House JI and Rose S (2013) How much land-based greenhouse gas mitigation can be achieved without compromising food security and environmental goals? Global Change Biology 19(8), 2285-2302. doi: 10.1111/gcb.12160.

Smith P, Bustamante M, Ahmmad H, Clark H, Dong H, Elsiddig EA, Haberl H, Harper R, House J, Jafari M, Masera O, Mbow C, Ravindranath NH, Rice CW, Robledo Abad C, Romanovskaya A, Sperling F and Tubiello F (2014) Agriculture, forestry, and other land use (AFOLU). In Edenhofer O, Pichs-Madruga R, Sokona Y, Farahani E, Kadner S, Seyboth K, Adler A, Baum I, Brunner S, Eickemeier P, Kriemann B, Savolainen J, Schomer S, von Stechow C, Zwickel T and Minx JC (eds). Climate Change 2014: Mitigation of Climate Change. Contribution of Working Group III to the Fifth Assessment Report of the Intergovernmental Panel on Climate Change. Cambridge, UK; New York, NY: Cambridge University Press, pp. 811-922. Available at https://www. ipcc.ch/pdf/assessment-report/ar5/wg3/ipcc_wg3_ar5_chapter11.pdf.

Sommer R and Bossio D (2014) Dynamics and climate change mitigation potential of soil organic carbon sequestration. Journal of Environmental Management 144, 83-87. doi: 10.1016/j.jenvman.2014.05.017.

Springmann M, Godfray HCJ, Rayner M and Scarborough P (2016) Analysis and valuation of the health and climate change cobenefits of dietary change. Proceedings of the National Academy of Sciences 113(15), 41464151. doi: 10.1073/pnas.1523119113.

Springmann M, Mason-D/'Croz D, Robinson S, Wiebe K, Godfray HCJ, Rayner M and Scarborough P (2017) Mitigation potential and global health impacts from emissions pricing of food commodities. Nature Climate Change, Nature Publishing Group 7(1), 69-74. doi: 10.1038/ nclimate 3155 .
Stadelmann M, Michaelowa A and Roberts JT (2013) Difficulties in accounting for private finance in international climate policy. Climate Policy, Taylor \& Francis 13(6), 718-737. doi: 10.1080/14693062.2013.791146.

Steckel JC, Jakob M, Flachsland C, Kornek U, Lessmann K and Edenhofer O (2017) From climate finance toward sustainable development finance. Wiley Interdisciplinary Reviews: Climate Change, John Wiley \& Sons, Inc. 8(1), e437-en/a. doi: 10.1002/wcc.437.

Swarts N, Montagu K, Oliver G, Southam-Rogers L, Hardie M, Corkrey R, Rogers G and Close D (2016) Benchmarking nitrous oxide emissions in deciduous tree cropping systems. Soil Research 54(5), 500-511. doi: 10.1071/SR15326.

Tassou S, De-Lille G and Ge Y (2009) Food transport refrigerationapproaches to reduce energy consumption and environmental impacts of road transport. Applied Thermal Engineering2 29(8), 1467-1477.

Temme EHM, Bakker HME, Seves SM, Verkaik-Kloosterman J, Dekkers AL, van Raaij JMA and Ocké MC (2015) How may a shift towards a more sustainable food consumption pattern affect nutrient intakes of Dutch children? Public Health Nutrition, 2015/09/07, Cambridge University Press 18(13), 2468-2478. doi: 10.1017/S1368980015002426.

Thapa R, Chatterjee A, Awale R, McGranahan DA and Daigh A (2016) Effect of enhanced efficiency fertilizers on nitrous oxide emissions and crop yields: a meta-analysis. Soil Science Society of America Journal, Madison, WI: The Soil Science Society of America, Inc. 80, 1121-1134. doi: 10.2136/sssaj2016.06.0179.

Thornton PK, van de Steeg J, Notenbaert A and Herrero M (2009) The impacts of climate change on livestock and livestock systems in developing countries: a review of what we know and what we need to know. Agricultural Systems 101, 113-127. doi: 10.1016/j.agsy.2009.05.002.

Tilman D and Clark M (2014) Global diets link environmental sustainability and human health. Nature, Nature Publishing Group, a division of Macmillan Publishers Limited. All Rights Reserved 515(7528), 518-522. doi: 10.1038/nature13959.

Tilman D and Clark M (2015) Food, agriculture \& the environment: can we feed the world \& save the earth? Daedalus, MIT Press 144(4), 8-23. doi: 10.1162/DAED_a_00350.

Tirado MC, Clarke R, Jaykus LA, McQuatters-Gollop A and Frank JM (2010) Climate change and food safety: a review. Food Research International, Elsevier Ltd 43(7), 1745-1765. doi: 10.1016/j.foodres.2010.07.003.

Tirado MC, Crahay P, Mahy L, Zanev C, Neira M, Msangi S, Brown R, Scaramella C, Coitinho DC and Müller A (2013) Climate change and nutrition: creating a climate for nutrition security. Food and Nutrition Bulletin, SAGE Publications Inc 34(4), 533-547. doi: 10.1177/ 156482651303400415.

Tirado MC, Hunnes D, Cohen MJ and Lartey A (2015) Climate change and nutrition in Africa. Journal of Hunger \& Environmental Nutrition, Taylor \& Francis 10(1), 22-46. doi: 10.1080/19320248.2014.908447.

van der Goot AJ, Pelgrom PJ, Berghout JA, Geerts ME, Jankowiak L, Hardt NA, Keijer J, Schutyser MAI, Nikiforidis CV and Boom RM (2016) Concepts for further sustainable production of foods. Journal of Food Engineering 168, 42-51.

van Dooren C, Marinussen M, Blonk H, Aiking H and Vellinga P (2014) Exploring dietary guidelines based on ecological and nutritional values: a comparison of six dietary patterns. Food Policy 44, 36-46. doi: 10.1016/ j.foodpol.2013.11.002.

Varanasi A, Prasad PVV and Jugulam M (2016) Impact of climate change factors on weeds and herbicide efficacy. In Advances in Agronomy, pp. 107-146. doi: 10.1016/bs.agron.2015.09.002.

Vermeulen SJ, Campbell BM and Ingram JSI (2012) Climate change and food systems. Annual Review of Environment and Resources 37, 195-222.

Vetter SH, Sapkota TB, Hillier J, Stirling CM, Macdiarmid JI, Aleksandrowicz L, Green R, Joy EJM, Dangour AD and Smith $P$ (2017) Greenhouse gas emissions from agricultural food production to supply Indian diets: implications for climate change mitigation. Agriculture, Ecosystems \& Environment 237, 234-241. doi: 10.1016/j.agee.2016.12.024.

Vieux F, Darmon N, Touazi D and Soler L (2012) Greenhouse gas emissions of self-selected individual diets in France: changing the diet structure or consuming less? Ecological Economics 75, 91-101. doi: 10.1016/j.ecolecon.2012. 01.003 . 
Vignola R, Harvey CA, Bautista-Solis P, Avelino J, Rapidel B, Donatti C and Martinez R (2015) Ecosystem-based adaptation for smallholder farmers: definitions, opportunities and constraints. Agriculture, Ecosystems \& Environment 211(suppl. C), 126-132. doi: 10.1016/j.agee.2015.05.013.

Vignola R, Leclerc G, Morales M and Gonzalez J (2017) Leadership for moving the climate change adaptation agenda from planning to action. Current Opinion in Environmental Sustainability 26-27(suppl. C), 84-89. doi: 10.1016/j.cosust.2017.03.005.

Vitousek P, Naylor R, Crews T, David MB, Drinkwater LE, Holland E, Johnes PJ, Katzenberger J, Martinelli LA and Matson PA (2009) Nutrient imbalances in agricultural development. Science 324(5934), 1519-1520. doi: 10.1126/science.1170261.

Wang L (2013) Energy consumption and reduction strategies in food processing. In Tiwari BK, Norton T and Holden NM (eds). Sustainable Food Processing. Chichester, UK: John Wiley \& Sons, Ltd.

Weaver CM, Dwyer J, Fulgoni VL, King JC, Leveille GA, MacDonald RS, Ordovas J and Schnakenberg D (2014) Processed foods: contributions to nutrition. The American Journal of Clinical Nutrition 99(6), 1525-1542. doi: 10.3945/ajen.114.089284.

Weber CL and Matthews HS (2008) Food-miles and the relative climate impacts of food choices in the united states. Environmental Science \& Technology 42(10), 3508-3513.
West TO and Post WM (2002) Soil organic carbon sequestration by tillage and crop rotation: a global data analysis. Soil Science Society of America Journal 66, 1930-1946.

Westhoek H, Lesschen JP, Rood T, Wagner S, De Marco A, Murphy-Bokern D, Leip A, van Grinsven $H$, Sutton MA and Oenema O (2014) Food choices, health and environment: effects of cutting Europe's meat and dairy intake. Global Environmental Change 26, 196-205. doi: 10.1016/j.gloenvcha.2014.02.004.

Wilson NLW, Rickard BJ, Saputo R and Ho S-T (2017) Food waste: the role of date labels, package size, and product category. Food Quality and Preference 55, 35-44. doi: 10.1016/j.foodqual.2016.08.004.

Yohe GW, Lasco RD, Ahmad QK, Arnell NW, Cohen SJ and Hope C (2007) Perspectives on climate change and sustainability. In Parry ML, Canziani OF, Palutikof JP, van der Linden PJ and Hanson CE (eds). Climate Change 2007: Impacts, Adaptation and Vulnerability, Contribution of Working Group ii to the Fourth Assessment Report of the Intergovernment Panel on Climate Change. Cambridge and New York: Cambridge University Press, pp. 811-841.

Zhang H, Wu J and Lu P (2011) A study of the radiative forcing and global warming potentials of hydrofluorocarbons. Journal of Quantitative Spectroscopy and Radiative Transfer 112(2), 220-229. doi: 10.1016/ j.jqsrt.2010.05.012. 